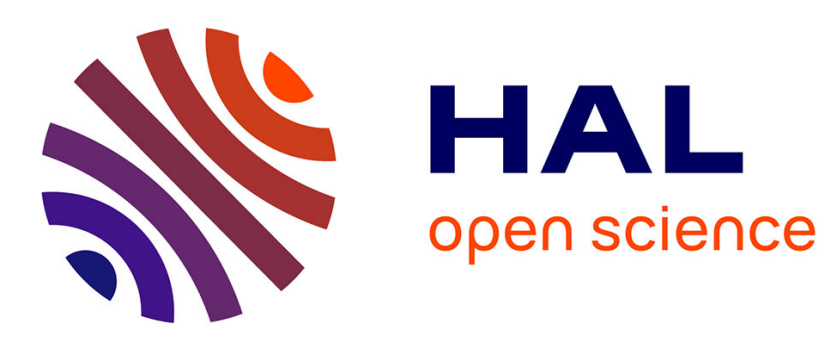

\title{
Providing coverage against new social risks in Bismarckian welfare states: the case of long-term care.
}

\author{
Nathalie Morel
}

\section{To cite this version:}

Nathalie Morel. Providing coverage against new social risks in Bismarckian welfare states: the case of long-term care.. G. Bonoli et K. Armingeon. The politics of post-industrial welfare states, Routledge, pp.227-247, 2006. halshs-00823686

\section{HAL Id: halshs-00823686 \\ https://shs.hal.science/halshs-00823686}

Submitted on 17 May 2013

HAL is a multi-disciplinary open access archive for the deposit and dissemination of scientific research documents, whether they are published or not. The documents may come from teaching and research institutions in France or abroad, or from public or private research centers.
L'archive ouverte pluridisciplinaire HAL, est destinée au dépôt et à la diffusion de documents scientifiques de niveau recherche, publiés ou non, émanant des établissements d'enseignement et de recherche français ou étrangers, des laboratoires publics ou privés. 


\title{
Providing coverage against new social risks in Bismarckian welfare states: the case of long term care.
}

\author{
Nathalie Morel \\ Laboratoire Georges Friedmann, \\ Université Paris I, France. \\ nathalie.morel@ffreesbee.fr
}

Publié dans : K. Armingeon et G. Bonoli (eds.) (2006), The politics of post-industrial welfare states, London, Routlegde.

Ageing populations, changing family models, women's increasing participation in the labour market and changing values and attitudes towards informal care-giving are new variables which are increasingly challenging the adequacy of present welfare systems by raising, amongst other things, the question of whose responsibility it is to care for dependent elderly people. Up until fairly recently, the care needs of the elderly have, in most countries, been considered a private family matter and have therefore not been a focus of attention for social policy makers. However, the present situation, characterised by a dwindling proportion of available carers coupled to an increasing proportion of people in need of care, has turned the private issue of care into a public concern in many countries. Long-term care for the elderly has thus come to be defined as a 'new social risk'.

The mid-1990s have witnessed the creation of new policies for dealing with the long-term care needs of the dependent elderly in several countries. In 1994, Germany created a fifth social insurance scheme to deal with dependency. In 1997, France set up a new social assistance benefit for the dependent elderly that was further expanded in 2002. Austria also opted for assistance benefits in 1993, while Luxemburg (1998) and Japan (voted in 1997 but implemented in 2000) followed the social insurance line.

The creation of these new policies is somewhat puzzling seeing as the 1990s have generally been described as a period of retrenchment or at least of "permanent austerity" for welfare states (Pierson, 2001). Indeed, faced with a global economic crisis, high unemployment, increasing pressure to keep budgets in check, but also adverse demographic trends, governments have attempted to reform the main insurance programmes, not least retirement pensions and health insurance in order to reduce or contain spending. Even more puzzling is 
the fact that all the above-mentioned countries are Bismarckian, conservative welfare states, generally perceived as the most "frozen" welfare states (Esping-Andersen, 1996). These countries are thought to face considerable difficulties in adapting to the new challenges posed to the welfare state (Scharpf and Schmidt, 2000, especially Vol. 1, chapter 1).

These policy developments therefore raise a series of questions. First of all, how can one account for these cases of policy expansion in times of austerity? Can traditional explanations of welfare state growth account for policy expansion in this field? Secondly, how and to what extent were these "frozen" conservative welfare states able to respond to the new challenge of the long-term care needs of the elderly? And why did some of these countries, all of Bismarckian inspiration and based on the social insurance principle, opt for a social insurance scheme while others chose social assistance as a policy response?

In dealing with these questions we focus on France and Germany only, each representing one of the two policy responses outlined above. As we will see, the very fact that these two countries did not choose the same policy option for responding to long-term care needs points to the social construction of the problem and to the importance of institutional and political factors in determining the options available. The comparison between these two countries thus allows us to gain a better understanding of the nature and dynamics of this process of expansion.

We argue that if ageing populations are indeed an objective fact and can be considered as a new social risk, this alone did not prompt governments to act. As we shall see, in both the French and German case, the problem for policy-makers was less the societal demand than the rising cost of programmes that had been diverted from their initial purpose. However, the programmes that suffered from rising costs were not the same in both countries thus calling for different policy responses.

In order to understand the policy process leading to the creation of new benefits for long-term care, we start by looking at how the dependent elderly were taken care of previously and at what was identified as the main problem(s). Secondly, we look at how the policy reform came about: what debates took place; what were the political, economic and institutional contexts; and who were the actors instrumental in bringing this issue on the agenda. In this respect, timing also emerges as an important variable. By looking at these different variables, we are 
able to test the different approaches which have been used for explaining welfare state development in the past and current literature, namely the functionalist approach, the power resources approach, and neo-institutional explanations, and see whether these also apply to policy making with regard to new social risks or whether other determinants need to be considered.

\section{A new social risk.}

\section{Ageing populations}

In the European Union, the number of people over the age of 65 will have more than doubled between 1960 to 2010, climbing from 34 to 69 million, a growth about ten times greater than for the total population which will only have increased by about $22 \%$ during the same period. The ageing of the population is also characterised by an increase in the category of people over 80, from 1.6\% in 1960 to 4.1\% in 2003. (Assous and Ralle, 2000 and Eurostat, 2004). Figures for France and Germany correspond to the EU average.

These figures are significant on many accounts. For instance, though it is by no means automatic, there is evidence that the risk of losing one's autonomy increases with age, 80 being somewhat of a turning point (DREES, 1999b). An ageing population therefore means a growing proportion of dependent people in need of care.

\section{Who cares?}

The dependent elderly have traditionally been taken care of by the family, especially in conservative welfare states where the principle of subsidiarity has long prevailed. Thus, in Germany in the early1990s, as much as $90 \%$ of the care services for the disabled and frail elderly living at home were provided informally by family members and, to a lesser extent, by other relatives, friends and neighbours (Götting et al., 1994). Figures were similar for France: about $80 \%$ of the frail elderly received care from family and other relatives. Of this group, $50 \%$ received informal help exclusively. About a third of the dependent elderly received both formal and informal help (Breuil-Genier, 1999). 
While this informal aid provided by the family has long been taken for granted, ageing populations is creating new pressures on the caring capacity of countries. Indeed, population ageing also entails a shrinking proportion of the population of caring age and therefore of potential carers. Since care work has traditionally been provided essentially by women mostly the daughters and daughters-in-law - Alber suggests that the caring capacity of a country can roughly be indicated by the ratio of women aged 45 to 69 to the number of people above that age. In Europe, this ratio was 30 percentage point lower in 1990 than in 1960 (Alber, 1995).

Population ageing is not, however, the only factor which has an impact on the supply of informal care. Another factor is the increasing participation of women in the labour market. This has reduced the number of women who are able or willing to take care of dependent elderly relatives.

\section{New social risk bearers}

It is this combination of scarce resources (in terms of potential carers) and of a new and rapidly growing demand that has led to what is increasingly being referred to as a "new social risk'. In this respect, it is important to note that while long-term care is generally thought of as a new risk for the frail elderly, it is also an important issue for caregivers whose employment patterns and career opportunities as well as access to social rights are affected by their caring responsibilities. Thus, when discussing long-term care needs as a new social risk it is important to distinguish between these two groups of "new risk bearers", not least as they may have conflicting interests.

This has important ramifications in terms of their capacity to mobilise around a unified goal, and therefore their capacity to bring the issue of long-term care needs on the political agenda. Indeed, what we can observe is that neither the elderly nor informal carers have been particularly active, at least in France and Germany, in bringing about policy changes. There are several reasons for that.

With respect to the elderly, it appears that those who are still healthy have some difficulty in projecting themselves into a situation of dependency - it is something they would rather not think about. In fact, this appears to be the case in the population at large, irrespective of age. 
This is as true of France (Frinault, 2003), as it is of Germany or the US (Campbell and Morgan, 2003). The frail elderly, for their part, have not mobilised either, and one can reasonably assume that this has to do with their very condition. In the case of informal caregivers, possible explanations are that caring for a dependent elderly parent is experienced as a moral duty and that it is a solitary activity which offers little potential for collective mobilisation.

The creation in 1994 of a social insurance scheme for long-term care needs in Germany (the 'Pflegeversicherung') and of a social assistance benefit in France in 1997 (the 'Prestation Spécifique Dépendance') cannot therefore be understood simply as governments responding to a strong societal demand. As we will see, changes in family patterns and female preferences have not been the key drivers of change.

\section{The problem is not the problem.}

Indeed, the family has not been the only actor providing for the frail elderly. Even before the Prestation Spécifique Dépendance and the Pflegeversicherung came about, the frail elderly were already receiving various forms of social help in both countries. In France, the frail elderly could claim the ACTP ('Allocation Compensatoire pour Tierce Personne') which is a cash benefit created in 1975 for disabled people. This benefit is means-tested and open to people who have permanent incapacities estimated at minimum $80 \%$ and who need help from someone in order to perform daily tasks. By the early 1990 s, over $70 \%$ of ACTP beneficiaries were dependent elderly people (Huteau et Le Bont, 2001). Following the decentralisation laws of 1983, this social assistance benefit has been managed by the 'départements', who also bear the cost of the programme.

In Germany, the high cost of professional care led many elderly people to poverty and also meant that many could not afford to receive the care they needed. Those most in need could claim social assistance benefits (Sozialhilfe). Benefits were means-tested and provided as a last resort, when no other income sources (including the income of the family) were available. The municipalities and the Länder were financially responsible for this programme. The increase in the number of dependent elderly during the 1970s and 1980s led to a dramatic increase in social assistance expenditure. Outlay on care nearly trebled between 1970 and 1976, and more than doubled during the subsequent decade (Götting et al., 1994). By 1992, 
out of the 42 billion DM (21,5 billion $€)$ spent on social assistance, 14.7 billion ( 7.52 billion $€)$ were spent on the dependent elderly (ibid.)

As the number of dependent elderly increased in both countries, both the ACTP and the Sozialhilfe came under pressure. The French 'départements' and the German municipalities and Länder sought to draw attention to the fact that these programmes had not been designed to deal with long-term care for the elderly and complained about the high cost of these programmes. It is from this point forward that the long-term care needs of the elderly became a social problem.

This appears quite clearly when one looks at the actors who mobilised to bring about policy change and at the arguments used and the options put forward for dealing with long-term care. In the following section, we will look at the process leading to the Pflegeversicherung in Germany in 1994 and then at the process in France that led to the Prestation Spécifique Dépendance in 1997 and subsequently to the Allocation Personnalisée d'Autonomie in 2002.

\section{Germany: from informal care to long-term care insurance.}

\section{Defining the problem.}

As mentioned above, the cost of social assistance in Germany began to increase rapidly especially in the early 1970s, due to the rising number of elderly people in need of long-term care. As a result, from the mid-70s onward, there was rising discontent on the part of the municipalities and Länder whose budgets were considerably strained.

The high cost of institutional care meant that more than two thirds of people living in nursing homes were dependent on social assistance. Some voices were raised against the fact that elderly people having worked all their lives could become stigmatised welfare claimants in old age, left with mere 'pocket money'. There was also growing concern that the supply of care would not be sufficient to meet the increasing demand. Indeed, policy-makers worried that fewer women might be willing to continue to care if the working conditions of informal carers did not improve. And finally, there were some doubts as to whether the supply and quality of professional services would be adequate to meet the increasing demand for care (Götting et al, 1994). 
Solutions put forward and position of the various actors.

Debates and a series of reports by experts ensued but without leading to any immediate action. Indeed, while there was broad consensus on the definition of the problem, there was less agreement on the type of answer to offer: while some favoured the creation of a separate insurance scheme for long-term care, others argued for a private insurance or even the status quo. Other options included the introduction of a universal tax-financed benefit with a shift of financial responsibility to the federal government or an expanded health insurance system.

The Kohl-led Christian-Democratic (CDU) government was initially opposed to any wideranging reform. The Christian Democrats, along with their Liberal (FDP) allies, argued that an increase in public intervention in the field of elderly care may undermine families' readiness to provide informal care and might also lead to an increase in institutional care. For the CDU, budget consolidation was to take precedence over social policy expansion. Thus little happened until 1988 when it was decided to make the statutory health insurance responsible for the support of home care in order to offer some relief to municipalities. This did not come into force, however, until 1991.

The next important step came shortly before the 1990 general election when Norbert Blüm, the CDU Minister of Labour and Social Affairs, announced that a new social insurance scheme for long-term care would be introduced during the following parliamentary term. Though members of his own party were divided on this issue, Blüm successfully argued that the CDU, as a "people's party" could not afford to ignore the older generation, emphasising the decisive electoral weight of the elderly.

Blüm's proposal for this long-term care insurance involved new social contributions paid in equal parts by employees and employers, as in the other social insurance schemes. This greatly displeased employers who argued that the risk of requiring long-term care was an individual life-risk, not a work-related risk. Thus they saw no reason why employers should be made to contribute (Hinrichs, 1996). They argued their case by pointing to the negative effects on competitiveness of a rise in non-wage labour costs. However, in their role as 'social 
partners', they refrained from opposing the reform entirely but they did seek to be exempted from the cost of it.

The more radical faction of the CDU, along with their Liberal allies, were also very much against the idea and favoured instead the development of a private insurance. However, this was discarded as unlikely to solve the problem. While private insurances did already exist, they had not been particularly successful in a field where people tend to greatly underestimate the risk $^{1}$. Furthermore, such an option would not be able solve the needs of the present elderly, as they would not be able to take out an insurance.

Blüm's proposal had this advantage over the private insurance option that it would benefit not just the elderly but also younger people in need of long-term care, and it could be effective immediately. A further advantage to his proposal was that it built upon the existing German social insurance tradition. In 1990, the social insurance system had not yet been called into question (this was clearly demonstrated by the way the West-German social insurance model was completely transposed to East-Germany following the reunification in 1989) and continued to enjoy popular support. The social insurance option was considered as an effective way to address social problems and was something policy-makers knew how to do.

The Social Democrats (SPD), for their part, supported the creation of a new social insurance scheme, partly because they believed it to be the best solution given the circumstances (a universal tax-financed benefit was not seen as politically feasible following the cost of the German reunification), and partly as a political strategy to undermine the CDU/CSU and FDP coalition. In fact, the SPD presented its own social insurance proposal in the summer of 1991.

Finally, the trade unions were rather favourable to a reform which would take away the stigma of means-testing but they did not mobilise as much on this issue as they did on other 'work-related' risks. They were also somewhat reluctant towards an increase in social contributions ${ }^{2}$.

\footnotetext{
${ }^{1}$ Campbell and Morgan (2003) show that this was the case not just in Germany but even in the US where private insurances against the risk of long-term care have not been very successful.

${ }^{2}$ For a more detailed account of the position of the different political parties and actors, see Götting et al., 1994.
} 
The idea of expanding the health insurance scheme in order to deal with long-term care needs was discarded almost as fast as the private insurance option. Indeed, there were already struggles over health care reform and the government was keen on keeping the issue of longterm care separate. Furthermore, sickness funds and physicians' associations opposed this proposal because of their interest in keeping the sickness insurance contribution rates low and to avoid creating more competition over scarce resources. It was also thought that a distinct scheme would give more salience to the reform and that the population would be more tolerant of additional social security payments if the money was clearly ear-marked for longterm care (Götting et al, 1994).

Making the issue of long-term care one of the cornerstones of the election campaign was somewhat of a gamble. First of all, as mentioned earlier, the people most concerned by this risk - that is the frail elderly and the informal caregivers - had not mobilised and pressed for change. Thus it was not known whether long-term care for the elderly would be a significant issue for the electorate: would there be any political benefits to implementing such a reform? Secondly, by making such an announcement, Blüm brought the issue of long-term care into focus, thus drawing voters' attention to it. This done, it became politically hazardous for him and his party not to act.

It thus became important to get the reform through in time for the following elections that were to be held in 1994. Extra pressure came in the form of the SPD presenting its own social insurance proposal in 1991. With both parties seeking to seduce the same potential electorate (pensioners and their children), getting the reform through became even more pressing for the CDU.

The main task was to convince the Liberals, employers and those inside the CDU who opposed this reform. Their concern was to keep employers from having to contribute to the cost of the reform. A compromise solution was finally reached whereby social contributions would be paid in equal shares by employers and employees, but in order to compensate employers for this extra cost, one paid holiday would be abolished. The reform was finally passed just before the 1994 general election.

It should be mentioned at this point that despite their disagreement on the type of scheme that should be implemented, all parties and actors had agreed on a few important points from the 
beginning. The first point was that home care should take precedence over care in nursing homes. Secondly, the scheme was not to cover the cost of room and board in nursing homes. In fact, the scheme should not cover the whole cost of care either. Thirdly, time spent in formal care work deserved credit within the pension scheme. The idea was to make caring more attractive so that caregivers, especially women of working age, would continue to care rather than enter the labour market. Indeed, the reform was by no means intended to reduce the quantity of care provided informally; in fact it provides measures aimed at encouraging informal care. These elements come out clearly both in the design of the Soziale Pflegeversicherung and in its outcomes.

\section{The German statutory long-term care insurance scheme (Soziale Pflegeversicherung)}

The law on long-term care insurance in Germany was voted in 1994 and implemented in two stages: in 1995 for domiciliary care cash benefits, and in 1996 for care in an institutional context. The long-term care insurance was set up as a fifth branch to the social insurance scheme and membership conditions are the same as for statutory health care. Insurance is compulsory for the entire population. Depending on employment status and income levels, citizens are either covered by the statutory scheme or must take out private insurance. In the latter case, the level of coverage must be at least equal to that offered by the statutory scheme.

The statutory scheme covers about $90 \%$ of the population and insures family members with no or limited income free of charge. Altogether, about 80 million people are insured (BMGS, 2003). It is a universal benefit, open to people of all ages rather than restricted to the elderly (in fact, $17,8 \%$ of recipients were under 60 years of age in 2002 (ibid.)). It is neither meanstested nor income-related.

The amount depends on the level of dependency (assessed by doctors affiliated with the health insurance funds) and on whether the person receives institutional or domiciliary care. In the case of domiciliary care, recipients can choose between cash benefits (Pflegegeld), inkind benefits or a combination of both. Benefits are not supposed to cover the whole cost of care. In 2003, the maximum benefit for the highest level of dependency was 665 euros per month for domiciliary care and 1432 euros for in-kind benefits. For the lowest level of dependency, these figures were respectively 205 and 384 euros (BMGS, 2003). 
The scheme is financed through social contributions levied on earnings up to a certain ceiling. These contributions (1.7\% of gross income) are split evenly between employees and employers. In 2001 there were 1.84 million people in receipt of benefits (Statistisches Bundesamt Deutschland, 2003).

France: more responsibilities for the 'départements'.

\section{Defining the problem}

In France, the problem of the long-term care needs of the elderly emerged in the 1970s but the term 'dependent elderly' did not appear until 1979 (Rapport Arrecks, 1979). A number of reports on the topic were produced in the 1980s and 1990s (Braun \& Stourm, 1988; Boulard, 1991; Schopflin, 1991; Laroque, 1993; IGAS, 1993), all of them highlighting the threat posed by the demographic situation as well as the inadequacy of existing services. The problems induced by the lack of coordination between the various medical and social institutions and the often poor quality of services were consistently pinpointed. The problem of financing was the other big concern. Despite this consensus on the diagnosis of the problem, these numerous reports did not lead to any political action for a long time.

It is in the early 1990s that the long-term care needs of the dependent elderly became a more serious issue for policy-makers. Indeed, the number of elderly people claiming disability benefits (ACTP) had increased dramatically to the extent that they represented $70 \%$ of beneficiaries. This cash benefit had been created for disabled people to partially cover the cost of hiring someone to help with daily tasks. Being a social aid benefit, it is financed and managed locally by the départements. An increase in the number of beneficiaries obviously entailed an increase in costs, much to the départements' displeasure.

The plight of the dependent elderly suddenly became a more pressing issue. Different arguments were put forth for creating a separate scheme. Firstly, it was argued that the ACTP was ill-adapted to the specific needs of the elderly, not least because the criteria of eligibility were poorly defined, the procedure too slow and the amount insufficient to cover the cost of long-term care in institutions (pointed out in the reports by Braun/Stourm, 1988; Boulard, 1991; Schopflin, 1991; see also Kessler, 1995). Secondly, there was some concern that the 
ACTP being a cash benefit, some people were misusing the money or even just saving it, and thus not receiving the care they needed (cf. Terrasse report, 2001).

This growing concern about the rising cost and misuse of the ACTP comes out clearly in a 1995 statement by the Senate regarding a law proposal for an autonomy benefit for the dependent elderly:

"The Law Commission has considered that while the proposed benefit does respond to a legitimate social preoccupation, its implementation should be realised within a coherent framework which should enable, first and foremost, to put a stop to the deficiencies of the present scheme, characterised in particular by the financial drift of the ACTP" (Sénat, 1995; my translation, emphasis added).

Another issue was the decline in the ratio between potential informal caregivers and the number of frail elderly. Here as in Germany, the issue became one of providing incentives to families to keep on caring, the rationale behind this being, of course, that informal care is much less costly than care in institutions, but also that too much state intervention is harmful to society as it makes families feel less responsible for their kin (a view, as we will see later on, shared by the Right and the Left alike).

Finally, all the reports linked "dependency" to old-age. This determined to a large extent the way the problem was subsequently treated in the political arena (Lafore, 2003). Indeed, what these reports identified were the specific needs of the dependent elderly (especially in terms of financial resources and in terms of getting access to better coordinated medical and social services), rather than loss of autonomy as a life-long risk. This in turn largely pre-defined the choice of response: in a Bismarckian context, the notion of risk calls for a social insurance response whereas that of need is linked to social assistance.

\section{Solutions put forward and position of the various actors}

As such, it comes as no surprise that there was very little debate on the choice of solutions. Although a few experts had mentioned in rather vague terms the possibility of creating a new social insurance scheme (mainly the 1988 Braun \& Stourm report and the 1993 IGAS report), 
this idea was never seriously considered by policy-makers. This general consensus around a new assistance benefit, managed by the départements has several explanations.

The first explanation has to do with the uncertainty that prevailed around the number of people concerned. Not only were there different predictions about the number of dependent elderly people in the future, there was also a lack of information about the number of people dependent at the time of these debates. The concern was therefore that the cost of the benefit would be very high and that a new benefit would also create more demand.

Secondly, the early 1990s in France were characterised by a bad economic situation with high unemployment (already $9.5 \%$ in 1991 and up to $12.3 \%$ in $1994^{3}$ ). The big deficit of the social security funds regularly made the headlines and the system itself was increasingly called into question. There was a fairly strong feeling that social contributions were too high and therefore damaging the competitiveness of French industries. As such, the idea of creating a new insurance scheme and therefore adding new social contributions did not have much appeal.

Finally, one has to consider the position of the various actors involved. It should be noted from the start that here as in Germany, neither the frail elderly nor the informal caregivers were mobilised.

Unsurprisingly, the employers' association (MEDEF) was clearly against the creation of a new social insurance, especially for the reasons just mentioned. The trade-unions, for their part, were generally favourable to such a reform as can be gathered from the consultations carried out by Brin in relation with the government's proposal in 1995 to create a new autonomy benefit (Brin, 1995). However, trade-unions did not actively press for a new insurance scheme as they did not consider the plight of the frail elderly as one of their main prerogatives, their attention being more focused on pensions and other work-related risks, and on preventing further increases in social contributions.

Unlike Germany, medical associations did not get involved much in the debate. More involved were the home-help associations and the directors of old-age homes: both these

\footnotetext{
${ }^{3}$ Compared to 5.6\% in Germany in 1991 and 8.4 \% in 1994 (Commission Européenne, 1999).
} 
groups called for a new social insurance scheme as such an option would allow for more stability in the profession and for greater professionalisation (Frinault, 2003).

The social security institutions in charge of health insurance (CNAM) or old-age insurance (CNAV) would have been likely candidates for managing a new long-term care insurance, however, neither showed much interest at the time (idem).

Politicians, for their part, were all concerned with limiting the cost of a new benefit and were all generally agreed that raising social contributions was not an option. They also rejected the idea of a new social insurance scheme as they wanted to avoid the risk of a policy lock-in effect (idem). Indeed, as attempts to reform the pension insurance in 1993 had already demonstrated, there is a high political cost attached to attempting to cut back insurance schemes. Tinkering with social aid benefits, on the other hand, does not usually meet with as much resistance. Political parties did differ on one point, which was that while those on the Right favoured a means-tested social aid benefit, the Left argued for a universal benefit. What the Left did not contest, however, was that the benefit would continue to be managed locally by the départements as a social assistance benefit.

Part of the explanation for this consensus is that following the decentralisation laws of 1983, the responsibility for social assistance has been transferred to the départements. The law specifies that if a new form of legal social aid is created, it would automatically be the responsibility of the département, unless the law stated otherwise.

Furthermore, it was felt that the départements had already gained some experience with the dependent elderly while administering the ACTP and that it would therefore be more efficient to take advantage of this experience rather than have some other institution manage the new benefit (a report by the Senate in 1995 emphasised "the long experience acquired by the départements in the field of social assistance", (Sénat, 1995)). This point was also made by the départements themselves who, as new actors, were keen to demonstrate their competency and legitimacy in the field of social intervention.

The départements also had some financial reasons for wishing to stay in charge of the dependent elderly. First of all, had the responsibility for this new benefit been transferred to the state or to a social security institution, the départements would have lost part of the 
subsidies they received for dealing with the elderly. Secondly, a law proposal for a new autonomy benefit drawn up in 1995 by Mrs. Codaccioni, the Minister for Solidarity between Generations, had led the départements to believe that they would receive new monies from the state. Indeed, this proposal suggested doubling the amount of money spent on the elderly through new state subsidies (Long, 1997). Even though in the end the proposal was not voted and such an increase in state subsidies did not materialise, the départements still considered it vital to be able to manage and control benefits for the dependent elderly as they themselves deemed fit in order to avoid the kind of economic difficulties linked to the ACTP (Frinault, 2003).

\section{The 1995 presidential election}

After years of debate, what finally prompted politicians to act were the presidential elections of 1995. Both the Left and the Right sought to appeal to pensioners who had become an important part of the electorate and to demonstrate their capacity to act. During the political campaign, Jacques Chirac (candidate for the Right) claimed that old-age dependency was a new social risk which, in the name of national solidarity, called for a collective response. He further suggested that time had come to take a step forward by quickly implementing a 'dependency benefit' ${ }^{4}$. On the political Left, Lionel Jospin announced that "Solidarity will have to be shown towards the dependent elderly whose number will increase and whom it will be essential to provide with the necessary care and attention they deserve. A complete scheme will be drawn up by the government: it will include a dependency benefit"

After Chirac's election, Prime Minister Juppé also promised the creation of a new benefit for the dependent elderly in his inaugural speech. The new government immediately proceeded to prepare a law proposal (the above-mentioned Codaccioni bill) which was highly criticised, not least by deputies on the Left who went so far as to appeal to the Constitutional Council on the grounds that the benefit proposed would lead to unequal treatment amongst citizens. A report by the Economic and Social Council (Avis Brin, 1995) was also very critical of this proposal.

\footnotetext{
${ }^{4}$ In « Extrait des réponses des candidats à l'élection présidentielle », Le Lien, ADMR, Avril 1995, quoted in CNRPA (1998).

${ }^{5}$ In « Propositions pour la France », programme de Lionel Jospin à l'élection présidentielle, quoted in CNRPA (1998).
} 
The government brought some modifications to its project and the law on the Prestation Spécifique Dépendance (specific benefit for dependency) was passed on January $24^{\text {th }}, 1997$.

However, this law was, from the beginning, a very unsatisfactory and transitory law as its title itself suggests:

Law $n^{\circ} 97-60$, tending, waiting for the vote of the law establishing an autonomy benefit for dependent elderly people, to better respond to the needs of the elderly by instituting a specific benefit for dependency. (Journal Officiel, January $25^{\text {th }}, 1997$, p.1280, my translation).

Thus was the lofty goal of promoting autonomy replaced by a more modest attempt at "better responding" to the problem of dependency.

\section{The 'Prestation spécifique dépendance' (PSD)}

The PSD came into force in January 1997. It is a means-tested benefit for people over the age of 60 , based on their level of dependency. It is a social assistance benefit, open to anyone residing in France. The benefit can be used for care received either in institutions or at home. The resources criteria are the same as for the ACTP. The allowance is not subject to tests regarding family obligations to maintain but the state can reclaim some of the cost on the elderly person's legacy or through mortgaging the person's estate.

The amount of the benefit is based on the person's resources as well as those of his/her spouse/partner, and on the level of dependency of the person, which is assessed by a sociomedical team according to a national grid (AGGIR-grid) that distinguishes between six levels of dependency. Only those who fall in groups 1,2 and 3 are entitled to the benefit.

The maximum amount of the benefit was $897 €$ per month in 2001. Only people whose total resources were below $9528 €$ a year could receive the maximum benefit (17318 $€$ for a couple). For people at or above that ceiling, the maximum benefit was $717 €$ per month (DREES, 2001). When personal resources and the benefit are added up, the total cannot exceed $10976 €$ a year for a single person, or $18294 €$ per year for a couple. Here as in Germany, the idea was not to cover the whole cost of care but rather to supplement and 
encourage the informal care provided by families (in both France and Germany the benefit can be used to pay an unemployed relative, other than a spouse, who provides care).

Though the maximum amount of the benefit was specified, no such guidelines were provided regarding minimum levels. This has meant that there were wide territorial disparities between the départements.

There were 86000 beneficiaries of the PSD in 1998 (DREES n 13, 1999). By 2001 the figure was only up to 139000 beneficiaries (DREES n 143 , 2001), which means that about $15 \%$ only of people who needed some form of care were covered by this scheme, according to INSEE estimates (Martin, 2003).

\section{Criticisms of the PSD}

This poor coverage of the population in need, along with the fact that there were wide territorial inequalities in terms of the amount paid to beneficiaries, led to increasing criticism which culminated in the production of a 'Black book of the PSD' (Le Livre noir de la PSD) in 1998, produced by the National Committee for Retired and Elderly People (CNRPA) along with over twenty different organisations of home-help services, elderly-care institutions, and NGOs. This 'Black book' argued for abolishing means-testing, for nation-wide regulations concerning the amount of the benefit and opposed the fact that the state could reclaim some of the cost on the elderly person's legacy or through mortgaging the person's estate. Indeed, this had been shown to effectively discourage elderly people from applying for the PSD. What the authors of this report wanted was a new social insurance scheme for dealing with long-term care, a position they further developed in their "White book for an autonomy benefit" (Livre blanc pour une prestation autonomie, 1999).

Basically, the PSD presented the same problems as the ACTP (variations between local authorities in terms of the amount paid and limited coverage of the population), which was hardly surprising as the PSD had been copied directly from the ACTP. The PSD therefore appeared largely as a cosmetic change to the way the dependent elderly were taken care of. The main change was for the départements who could better control the way benefits were provided. 
However, even the départements were dissatisfied with this new benefit, essentially because they did not receive the extra subsidies they had anticipated. Many départements also began to press for change. After the 1997 legislative elections that propelled the Left into government, there was hope for change as the Left had shown a clearer preference for a collective solution to the care needs of the elderly and had been very critical towards the types of inequalities engendered by the PSD. They had even voted against the PSD.

Despite all this, the socialist-led government did not do anything for four years. There were several reasons for this as pointed out by Frinault (2003). First of all, the dependent elderly were not a top priority for the then Minister of Employment and Solidarity, Martine Aubry. Indeed, the legislation on the 35-hour week, the creation of the CMU (a universal health coverage scheme), and the development of the 'emplois-jeunes' (a youth employment scheme) were more pressing issues for the government. Secondly, the European Union context represented a constraining environment for developing new and expensive social insurance schemes.

These were not the only reasons, however. There were also more ideological and institutional reasons for this lack of enthusiasm for the creation of a new insurance scheme as Aubry's speech before the national Committee for Geriatric Coordination in April 1999 illustrates. Her three main points were, first, that a social insurance benefit would still have to be meanstested as, whatever the mode of financing, the community could not ignore the resources of a person in determining how much help that person should receive. Secondly, "unlike a health service which requires input from professionals, help to a dependent elderly person relies in actual facts first and foremost on relatives (spouse, children or other) and only secondarily on the intervention of professionals. To reverse this order by making the community finance a substitutive rather than a subsidiary benefit would lead to the destruction of natural family solidarity, which would have a very high cost for society" (emphasis in the original). Finally, "the PSD should remain something managed locally in order to be as close to the needs as possible. A benefit granted automatically on the basis of a national needs-scale would not be well adapted. Help should be calibrated within a framework of personalised aid plan which takes into account the help provided by relatives and which is inserted within the framework of a real local geriatric coordination, which relies on the local actors" (Martine Aubry, April 1999, my translation). 
Since it was clear that the PSD had to be reformed nonetheless, Aubry commissioned JeanPierre Sueur in December 1999 to write a report on a new autonomy benefit that would be more equal across the country and would cover a much larger proportion of the elderly in need of care. However, his mission statement clearly indicated that an insurance scheme involving new social contributions was out of the question. The report came out in May 2000 and was followed by a law on a new personalised autonomy benefit (Allocation Personnalisée d'Autonomie).

\section{The 'Allocation Personnalisée d'Autonomie' (APA)}

Voted in 2001, the APA came to replace the PSD in January 2002 and sought to remedy some of the main problems identified with the PSD. First and foremost, although it remains a social assistance scheme, managed at the regional level, it guarantees the same access to benefits everywhere in France. The state redistributes resources across all the départements to compensate for the differing levels of resources.

The benefit has been extended to people who fall in level four (GIR 4) according to the AGGIR grid, which has considerably increased the number of people eligible for this benefit. Levels of dependency continue to be assessed by a socio-medical team and benefits can be claimed either for institutional or domiciliary care.

The benefit is no longer means-tested but the amount is reduced progressively (from $0 \%$ to $80 \%$ ) for beneficiaries who have resources in excess of 949 euros a month. This is referred to as the "ticket modérateur", a term borrowed from the social insurance vocabulary. In January 2002, the maximum benefit for domiciliary care for people in GIR 1 was 1090 euros per month, it was 935 euros for GIR 2, 701 euros for GIR 3 and 467 euros for GIR 4 (DREES $\left.\mathrm{n}^{\circ} 226,2003\right)$. The state can no longer reclaim some of the cost on the person's legacy.

By December 2002 there were 605000 APA recipients (idem.). This figure is expected to increase to 800000 by 2005 (Sueur, 2002). In the Sueur report that paved the way to the reform, the cost of the APA was estimated at 2.5 billion euros. As it turns out, the cost has risen to 3.7 billion euros, which has prompted the right-wing Raffarin-led government to introduce new reforms in 2003 to reduce the cost of this benefit. 
This reform lengthens the delay before receiving the benefit, it introduces control mechanisms on the way the benefit has been spent by the beneficiary and, most controversial of all, it dramatically reduces the income-ceiling below which one is entitled to full benefits (from 949 euros down to 623 euros).

\section{What impact on new social risk bearers?}

In Germany, the introduction of the long-term care insurance scheme has considerably improved the financial situation of the frail elderly and reduced the risks associated with dependency. However, because the benefits do not cover the whole cost of care, many continue to be dependent on social assistance. As a result, the Pflegeversicherung is increasingly being contested.

In France the situation was a lot less favourable to the elderly following the PSD than it was in Germany, but the introduction of the APA in 2002 marked a clear improvement. Indeed, the APA was so successful that the number of beneficiaries - and with it the cost of the benefit - increased more rapidly than had been expected. Only a year after it was implemented, the new right-wing government started cutting back on it. This was made possible by the very nature of the scheme, which - although universal - remains a meanstested social aid benefit (Palier, 2002a).

While there have been some positive outcomes for the frail elderly, it is nonetheless important to emphasise that the plight of the dependent elderly was not the main concern in either country. As several authors have pointed out, the debates that led to the introduction of the long-term care insurance scheme in Germany focused essentially on the rising number of frail elderly people dependent on social assistance, and on rising municipal expenses. Issues such as the situation of informal caregivers or the quality of care played but a subordinate role (Götting et al., 1994; Schneider, 1999). Very much the same can be said about France: it was the rising number of dependent elderly claiming the ACTP - a social benefit originally designed for the disabled - that fuelled the debate and prompted policy-makers to act.

Of even less concern was the situation of informal caregivers. In both countries, the main objective was to find ways of getting the families, and not least women, to keep on caring. In fact, despite the introduction of long-term care schemes in both France and Germany, figures 
for informal care have remained virtually the same as a decade ago. Thus in France, amongst the 3.2 million frail elderly who receive some form of help, about half of them receive only help from family and friends or neighbours, while $29 \%$ receive both professional and informal help. Only $21 \%$ receive only formal help (DREES, ${ }^{\circ} 142,2001$ ). In Germany, $70.3 \%$ of beneficiaries received domiciliary care in 2001 and of those, $72.6 \%$ had opted for cash benefits (BMGS, 2003). These figures indicate that the introduction of the long-term care insurance has not eroded the provision of informal care; the main difference with the early 1990s is that informal carers now receive some form of payment and social security rights.

\section{Discussion and conclusion}

We started off with two main questions: how come France and Germany, both "frozen" conservative welfare states, each introduced new policies for dealing with the long-term care needs of the frail elderly at a time generally described as a period of retrenchment or at least of 'permanent austerity'? Put differently, how could one account for these cases of policy expansion and were traditional explanations of welfare state growth able to account for this expansion? Secondly, why did Germany opt for a social insurance scheme while France, breaking with its social insurance model, implemented a social assistance benefit?

\section{Traditional theories of welfare state growth}

A functionalist approach would suggest that these new policies were created to deal with what appeared as an increasingly important new social risk, that of requiring long-term care in old age. The argument would be that the process of modernisation of societies, characterised amongst other things by family break-ups and new family forms, changing values, women's labour market participation, etc. has weakened the traditional modes of social protection, thus requiring the state to step in as a substitute. However, as the case studies of France and Germany illustrate, the problem for policy-makers was less the societal demand than the rising cost of programs that had been diverted from their initial purpose. Furthermore, it was clear in both countries that the state should not step in as a substitute but rather encourage and reinforce informal care structures. Finally, the choice of different policy responses in Germany and in France demonstrates that "needs" do not automatically dictate appropriate "solutions", i.e. political solutions are not selected or designed only according to functional 
requirements (cf. Götting et al.'s discussion of the German Pflegeversicherung, 1994). One therefore cannot assume some kind of direct causality between problems and policy.

Theories of welfare state growth based on the power resources approach - i.e. explanations based on the relative strength of the labour movement and/or of Left-wing parties in the government - are also unsatisfactory. The power resources approach does help to account for the conservative and weakly decommodifying nature of the policies (in that they encourage informal care-giving) since both the Pflegeversicherung and the PSD were introduced by Right-wing governments. However, it does not help to understand why these policies were created in the first place. Indeed, there was neither any class mobilisation nor even any mobilisation on the part of new social groups - in this case the new social risk bearers. Even trade-unions, who should have been a strong component of a group-based mobilisation, failed to mobilise in both countries due to the nature of this new 'risk', which was not perceived to be work-related.

Neo-institutionalist accounts prove more fruitful. Indeed, as we have argued, it was not the ageing of the population per se that was the problem. This had been going on for twenty years already and had been highlighted in several reports without policy-makers doing anything about it. It is only once certain institutions were affected by these demographic trends (in terms of rising costs and in terms of programmes being diverted from their initial purpose) that the problem became an issue for policy-makers. What the latter were responding to was the growing discontent not of the elderly and the caregivers but of the institutions that were thus put under pressure. In fact, because it highlights certain mechanisms of path-dependency, historical neo-institutionalism also helps to account for the different responses offered in France and Germany.

\section{Explaining differences in France and Germany}

As we have seen, gaining support for the creation of a new social insurance scheme was not a straightforward task in either country. This difficulty was linked to the nature of the risk in question. Indeed, long-term care of the elderly was not perceived as a work-related risk. As such, it was difficult for Bismarckian welfare systems to agree to finance this 'risk' through social contributions paid by employees and employers. In Germany, the fact that needing long-term care was defined as a risk, independently of age and cause, made it easier to justify 
that the employers contribute also (not least because loss of autonomy linked to work injuries is covered by this scheme). In France, on the other hand, long-term care was defined as a need linked to old age. Needs, in a Bismarckian welfare state, are associated with social assistance.

However, the choice of vocabulary for defining this 'new' problem in each country was not done randomly or innocently. In Germany, faith in the social insurance model was still strong at the time of the debates and the economy was still quite healthy. Even though raising social contributions was no longer a straightforward choice (policy-makers were trying to restore the country as a profitable place of investment and production (Götting et al., 1994)), neither was raising taxes due to the increase that had already taken place following the reunification of East and West Germany. The municipalities and Länder had clearly stated their wish to be rid of the financial burden of providing for the needs of the frail elderly and were in a sufficiently strong political position to push for a shift of financial responsibility. Thus it was necessary to find new actors to put in charge of the needs of the frail elderly. Getting the social partners (employers and employees) to manage a new insurance scheme was made possible by effectively relieving employers of the cost of the new insurance by compensating them through the abolition of a paid holiday. This way, the cost of labour did not increase for employers and allowed Germany to remain competitive. So in developing a long-term care insurance, Germany stuck to the well-trodden path of social insurance ${ }^{6}$.

In France the debate was about "old-age dependency" rather than long-term care. There was no discussion about dependency or loss of autonomy as a risk that could befall people at any age, nor was there any discussion about adopting a more global approach to disability and lack of autonomy. This is rather surprising seeing as the elderly had for some years been taking advantage of the disability benefit (ACTP). Expanding this benefit so that it could respond to the needs of both the elderly and the disabled would have made good sense ${ }^{7}$. Instead, in line with the French tradition of putting people into discreet categories of intervention (a tradition inherited from the social assistance model of the Third Republic), a new category of 'dependent elderly' was identified. This choice was also linked to the fact that the départements, who were managing the ACTP and who had therefore found

\footnotetext{
${ }^{6}$ Though it should be pointed out that unlike for the other four traditional insurance schemes, benefits are flatrate rather than income-related.

${ }^{7}$ That this was not done has in fact raised some new problems. Indeed, disabled people find that they lose their right to disability benefits when they turn 60 and have to rely on the less well-adapted dependency benefit thereafter. Yet, as some commentators have pointed out, disability does not 'retire' at the age of 60 !
} 
themselves in charge of the dependent elderly, were the ones who effectively mobilised to not only create a new benefit, but also to be put in charge of this new benefit. This was both because they were hoping for fresh subsidies and because they wanted to gain more legitimacy as social actors. Furthermore, the decentralisation laws of 1983 specified that any new form of legal social aid should be the responsibility of the départements. There were therefore strong institutional reasons to continue along the same path.

However, another important factor in the French decision to quickly discard the idea of a new insurance was the economic and employment situation at the time. As a result, it was felt that raising social contributions was simply not an option. Indeed, since the late 1980s, governments of different political orientations have adopted contribution-exemptions for employers in order to encourage job creation, most prominently through the creation of the CSG (the generalised social contribution) in 1990 (Palier, 2002b). Finally, contrarily to Germany, there was less faith in the insurance model due to the important budgetary difficulties experienced by the Social security.

\section{New political determinants for new social risk policies?}

There was nonetheless one common factor in the development of long-term care policies in France and Germany that needs to be emphasised: in both countries the policy reforms were part of a promise made during the campaign for the general elections. Politicians seized upon this issue of long-term care in the hope to attract voters, not least as the elderly represent an increasingly important part of the electorate. This credit-claiming opportunity is most likely an important determinant in accounting for why parties on both the Right and the Left vied with each other to introduce new policies, even in times of 'austerity'.

Less evident is whether the shape taken by these reforms is explicable with reference to this context of general 'austerity' (preventing policy-makers from launching costly, large-scale programmes) or whether it is due to deeply entrenched values in these Bismarckian countries regarding the proper equilibrium between state and family in the provision of care. Indeed, the new policies did not bring any fundamental change to the care structure (care continues to be provided essentially informally - even if care-givers now receive some form of payment), what has changed is the mode of financing and of management. The main trigger for the development of these policies was the appearance of structural or institutional problems: some 
programmes were being 'misused' and therefore saw their cost rising exceedingly. It was to deal with that, rather than merely with a newly recognised social 'risk' that policy-makers sought to develop new schemes. Thus, without dismissing the fact that these reforms marked a clear improvement for citizens in both countries, one could argue that these new policies aimed first and foremost at restructuring the existing welfare state, rather than at recasting and expanding it.

\section{References}

Alber, J. (1995), “A framework for the comparative study of social services", Journal of European Social Policy, 5(2):131-149.

Arreckx, M. (1979), L'amélioration de la qualité de vie des personnes âgées dépendantes, Paris, Editeur Assemblée nationale.

Assous, L., Ralle, P. (2000), "La prise en charge de la dépendance des personnes âgées : une mise en perspective internationale", DREES, Collection "Etudes", n¹, juin.

Aubry, M. (1999), « Discours de Martine Aubry, Ministre de l'emploi et de la solidarité, au Comité National Gérontologique », jeudi 29 avril 1999.

Boulard, J.C. (1991), Vivre ensemble, Rapport d'information déposé par la Commission des Affaires culturelles, familiales et sociales sur les personnes âgées dépendantes. Assemblée Nationale, $n^{\circ} 2135$, juin 1991, Paris.

Braun, T., Stourm, M. (1988), Les personnes âgées dépendantes, Rapport d'étude de la commission nationale sur les personnes âgées dépendantes, Paris, La Documentation française.

Breuil-Genier, P. (1999) "Aides aux personnes âgées dépendantes: une très grande hétérogénéité des pratiques", in MIRE, Comparer les systèmes de protection sociale en Europe du Nord et en France, Vol.4(1), Paris, MIRE-DREES.

Brin, H. (1995), Projet de création d'une "prestation autonomie » destinée aux personnes âgées dépendantes, Avis présenté au nom du conseil économique et social, séances des 12 et 13 septembre 1995. Journal Officiel, Avis et Rapports du CES, 1995, n4, vendredi 15 septembre 1995.

BMGS (Bundesministerium für Gesundheit und Soziale Sicherung / Federal Ministry of Health and Social Security Schemes) (2003), "Zahlen und Fakten zur Pflegeversicherung" and "Soziale Pflegeversicherung. Leistungsempfänger nach Altersgruppen und Pflegestufen am 31.12.2002", http://www.bmgs.bund.de 
Campbell, A. and Morgan, K. (2003), "Federalism, risk-pooling, and social policy: the politics of long-term care in Germany and the United States", paper presented at the RC19 conference, Toronto, Aug.21-24, 2003.

CNRPA et al. (1998), Le livre noir de la PSD.

CNRPA et al. (1999), Livre blanc pour une prestation autonomie, Paris, La Doc. Française.

Commission Européenne (1999), L'emploi en Europe 1998, Luxembourg, OPOCE.

DREES (1999a), "La prestation spécifique dépendance. Premier bilan au 31 décembre 1998", Etudes et Résultats, $\mathrm{n}^{\circ} 13$.

DREES (1999b), "Les personnes âgées dans les années 90 perspectives démographiques, santé et modes d'accueil", in Etudes et Résultats, n 40.

DREES (2001), "Les aides et les aidants des personnes âgées", Etudes et Résultats, nº142.

DREES (2001), "La prestation spécifique dépendance au 30 juin 2001", Etudes et Résultats, $\mathrm{n}^{\circ} 143$.

DREES (2003), "L'allocation personnalisée d'autonomie au 31 décembre 2002", Etudes et Résultats, $\mathrm{n}^{\circ} 226$.

Eurostat (2004), "EU population: People by age classes", http://europa.eu.int/comm/eurostat/

Frinault, Thomas (2003), "L'hypothèse du $5^{\mathrm{e}}$ risque", in Martin, C. (ed.) (2003), La dépendance des personnes âgées. Quelles politiques en Europe?, Rennes, PUR.

Esping-Andersen, G. (ed.) (1996), Welfare States in Transition, National Adaptations in Global Economies, London, Sage.

Götting, U., Haug, K., Hinrichs, K. (1994), "The Long Road to Long-Term Care Insurance in Germany”, Journal of Public Policy, 14(3):285-309.

Hinrichs, K. (1996), 'L'assurance soins de longue durée : une innovation institutionnelle de la politique sociale allemande", in MIRE Vol.2, Comparer les systèmes de protection sociale en Europe, Paris.

Huteau, G. et Le Bont, E. (2001), Sécurité sociale et politiques sociales, Paris, Armand Colin.

IGAS (1993), Rapport sur la dépendance des personnes âgées.

Journal Officiel (1997), Loi $n^{\circ} 97-60$ tendant, dans l'attente du vote de la loi instituant une prestation d'autonomie pour les personnes âgées dépendantes, à mieux répondre aux besoins des personnes âgées par l'institution d'une prestation spécifique dépendance, JO du 25 janvier 1997, p.1280.

Kessler, F. (1995), "Quelles prestations pour les personnes âgées dépendantes? Panorama des propositions de réforme", Droit Social, (1):85-94. 
Lafore, R. (2003), "La prestation spécifique dépendance et la construction de l'action publique", in Martin, C. (ed.) (2003), La dépendance des personnes âgées. Quelles politiques en Europe?, Rennes, PUR.

Long, M. (1997), "La prestation d'autonomie, une nécessité reportée", Revue française des affaires sociales, $\mathrm{n}^{\circ}$ hors série, pp.247-261.

Martin, C. (ed.) (2003), La dépendance des personnes âgées. Quelles politiques en Europe? Rennes, PUR.

Palier, B. (2002a), Gouverner la Sécurité sociale, Paris, PUF.

Palier, B. (2002b), "Tracing the Political Processes of Path-Breaking Changes in French Social Policy", paper presented at the APSA meeting in Boston, 2002.

Pierson, P. (2001), "Coping with Permanent Austerity: Welfare State Restructuring in Affluent Democracies", in The New Politics of the Welfare State, Oxford, OUP.

Scharpf, F., Schmidt, V. (eds). (2000), Welfare and Work in the Open Economy. Vol. 1: From Vulnerability to Competitiveness, Oxford, OUP.

Schneider, U. (1999), “Germany's social long-term care insurance: design, implementation and evaluation", International Social Security Review, 52:31-74.

Schopflin, P. (1991), Dépendances et solidarités. Mieux aider les personnes âgées, rapport au Commissariat général du Plan, Paris, La Documentation française.

Sénat (1995), Avis présenté au nom de la commission des lois constitutionnelles, de législation, du suffrage universel, du règlement et d'administration générale sur le projet de loi instituant une prestation d'autonomie pour les personnes âgées dépendantes (Rapporteur: Girod, Paul). Publications du Sénat, 1995-10-31, n55, pp. 1-47, Paris, La Documentation française.

Statistisches Bundesamt Deutschland (Federal Statistical Office Germany) (2003), http://www.destatis.de

Sueur, J-P. (2000), L'aide personnalisée à l'autonomie: un nouveau droit fondé sur le principe d'égalité, rapport remis à Martine Aubry Ministre de l'emploi et de la solidarité, Paris, La Documentation française.

Terrasse, P. (2001), Rapport fait au nom de la Commission des Affaires Culturelles, Familiales et Sociales sur le projet de loi ( $\left.n^{\circ} 2936\right)$ relatif à la prise en charge de la perte d'autonomie des personnes âgées et à l'allocation personnalisée d'autonomie. 